Prohilila(Produksi....., Shalahuddin, Farida, Rohani, Shibghatun, Tiara

\title{
PROHILILA(PRODUKSI HIDROGEN DARI LIMBAH LABORATORIUM) SEBAGAI MEDIATOR ENERGI PEMBANGKIT LISTRIK DENGAN METODE FUEL CELL
}

\author{
Shalahuddin Al Madury, Farida Fakhrunnisa, Rohani \\ Panjaitan, Shibghatun Ni'mah, Tiara Permata Chandra. \\ Jurusan Farmasi, Fakultas MIPA
}

\begin{abstract}
ABSTRAK
Laboratorium merupakan sarana dalam pengembangan ilmu pengetahuan khususnya dalam bidang keilmuan dalam menunjang keberhasilan penemuan hal-hal baru melalui penelitian. Mengingat banyaknya jenis limbah lab FMIPA UII yang berbahaya, termasuk juga limbah cair dari laboratorium yang bersifat toksik yang memiliki unsur logam berat sehingga mencemari lingkungan serta bepengaruh pada kesehatan manusia. Maka diperlukan upaya untuk pengatasan serta memberikan inovasi baru dari limbah cair kimia. Salah satunya dilakukan pengelolaan menggunakan teknik fuel cell yang merupakan energi masa depan yaitu sistem elektrokimia yang dapat mengubah energi kimia dari hidrogen dan oksigen yang langsung menjadi energi listrik. Keuntungannya pembakaran lebih konvensional yang berbasis teknologi dan tidak memancarkan emisi pada saat operasi, merupakan green house gases mengatasi polusi udara. Pemanfaatan limbah laboratorium dengan metode fuel cel ini bertujuan agar pencemaran lingkungan oleh zat kimia dapat diminimalkan dan dapat mengubahnya menjadi daya energi listrik. Untuk mendukung gagasan ini, maka perlu dilakukannya studi lebih lanjut mengenai proses pemanfaatan limbah menjadi energi listrik menggunakan metode fuel cell. Dimana dengan menggunakan fuel cell, satu $\mathrm{kg} \mathrm{H}_{2}$ dapat menghasilkan 33,9 kWh energi listrik atau sama dengan 33.900 watt per jam. Prediksi hasil dari pemanfaatan limbah ini yaitu terbentuknya kemandirian untuk memenuhi kebutuhan listrik terutama di laboratorium hingga dapat memberikan solusi untuk menghasilkan energi yang terbarukan.
\end{abstract}

Keywords: fuel cell, limbah cair, pembangkit listrik

PENDAHULUAN

\section{Latar Belakang}

Kegiatan laboratorium seperti kegiatan praktikum mahasiswa sebagai pembelajaran kurikulum layaknya kondisi di industri yang merupakan salah satu kegiatan penting bagi mahasiswa dalam pengembangan ilmu pengetahuan dan penelitian pada bidang masing- 
masing. Urgensi kegiatan praktikum ini menunjang pakar keilmuan dari pengetahuan dengan melakukan penelitian.Salah satu contoh sebagai objek dalam kegiatan praktikum mahasiswa terletak di Laboratorium Fakultas Matematika dan IImu Pengetahuan Alam Universitas Islam Indonesia di Yogyakarta yang memiliki peranan penting dalam mendukung program pembelajaran. Hal ini terbukti dari persentase banyaknya praktikum dengan mata kuliah yang ada di FMIPA UII, berdasarkan buku panduan akademik FMIPA UII menunjukkan bahwa untuk program studi farmasi mencapai $27 \%$ praktikum per semesternya, untuk prodi ilmu kimia $25 \%$, sedangkan untuk prodi D3 analis mencapai 33\% (Anonim, 2011).

Persentase diatas menunjukkan intensitas kegiatan praktikum di lab FMIPA dikategorikan cukup sering. Setiap praktikummenggunakan bahanbahan kimia, tentu akan menghasilkan limbah kimia juga. Berbagai macam jenis limbah yang bersumber dari laboratorium diantaranya, limbah padat yang seperti sisa pemakaian bahan kimia padat, masker, sarung tangan, kertas, plastik, dan kaca. Begitu juga denganlimbah cair, yang bersumber dari sisa air buangan laboratorium, bahkan limbah zat kimia sisa dari penelitian dilaboratorium yang apabila dikumpulkan satu lab FMIPA setiap semester menghasilkan lebih dari 300 liter.Kedua jenis limbah tersebut yang lebih berbahaya adalah pada limbah cair sisa zat kimia. Tanjung (2002) menyatakan bahwa limbah yang sangat ditakuti adalah limbah dari logam industri kimia yang mengandung berbagai macam unsur logam berat dan beracun atau toksik sehingga berbahaya bagi kesehatan manusia.

Untuk pengatasan limbah cair di laboratorium FMIPA UII sendiri selama ini hanya sebatas pada pengumpulan kemudian dinetralkan agar tidak toksik dan dibuang melalui serapan tanah. Upaya pengatasan limbah seperti ini tentunya masih menimbulkan kehawatiran, mengingat bahaya yang dapat ditumbulkan dari limbah cair zat kimia sangat banyak diantaranya penyakit yang timbul seperti gangguan pernapasan (penyempitan bronkus) atau terkena kanker paru yang menyebabkan kematian bahkan penyakit kardiovaskular dan timbul cacat bawaan serta penyakit kulit akibat tersebar ke perairan rumah tangga menyebabkan penyakit kulit(Thomas,2005). Meskipun dengan adanya penetralan, masih di khawatirkan limbah cair dari zat kimia yang mengandung unsur logam berat meliputi Sulfur, Nitrogen Oksida, Merkuri yang memiliki dampak negatif bagi lingkungan serta dapat menimbulkan kerusakan sumber daya alam yang menurunkan kualitas hidup karena lingkungan menjadi kotor dan tercemar(Supraptini,2002). 
Banyak cara yang dapat dilakukan untuk mengelola limbah cair. Indonesia sendiri sejauh ini pengolahan limbah cair dilakukan melalui beberapa metode. Metode yang digunakan dalam pengolahan air limbah adalah kunci dalam memelihara kelestarian lingkungan. Adapun macam teknologi pengolahan air limbah industri yang dibangun harus dapat dioperasikan dan dipelihara oleh perusahaan setempat. Berbagai teknik pengolahan air buangan untuk menyisihkan bahan polutannya telah dicoba dan dikembangkan selama ini.Teknikteknik pengolahan air buangan yang telah dikembangkan tersebut secara umum terbagi menjadi 3 metode pengolahan.

Pertama, pengolahan secara fisika yaitu dilakukan terhadap air buangan agar bahan tersuspensi yang berukuran besar mudah mengendap atau bahan yang terapung disisihkan dengan cara penyaringan. Parameter pengendapan ini adalah kecepatan mengendap partikel dan waktu retensi pengendapan yang sebelumnya dilakukan pemisahan cair dengan padatan melalui proses flotasi untuk menyisihkan bahan yang mengapung, preses filtrasi untuk menyisihkan bahan yang tersuspensi, proses adsorbsi untuk menyisihkan senyawa aromatik,dan teknologi membran untuk menggunakan kembali air yang diolah. Kedua, pengolahan secara kimia yaitu pengolahan air buangan secara kimia biasanya dilakukan untuk menghilangkan partikel-partikel yang tidak mudah mengendap (koloid), logam-logam berat, senyawa fosfor, dan zat organik beracun dengan membubuhkan bahan kimia tertentu yang diperlukan.

Penyisihan bahan-bahan tersebut pada prinsipnya berlangsung melalui perubahan sifat bahan-bahan tersebut, yaitu dari tak dapat diendapkan menjadi mudah diendapkan (flokulasikoagulasi), baik dengan atau tanpa reaksi oksidasi-reduksi, dan juga berlangsung sebagai hasil reaksi oksidasi, dan ketiga pengolahan secara biologi yang ditinjau dari segi lingkungan proses penguraian secara biologi dapat dibedakan dengan dua jenis yaitu proses aerob yang berlangsung hadirnya oksigen dan proses anaerob yang berlangsung tanpa oksigen. Apabila BOD air buangan tidak melebihi $400 \mathrm{mg} / \mathrm{l}$, proses aerob masih dapat dianggap lebih ekonomis dari anaerob. Pada BOD lebih tinggi dari $4000 \mathrm{mg} / \mathrm{l}$, proses anaerob menjadi lebih ekonomis(Anwar,2007). Salah satu metode pengolahan secara fisika yaitu secara fuel cell.

Fuel cell adalah suatu sistem elektrokimia yang mengubah energi kimia dari hidrogen dan oksigen langsung menjadi energi listrik. Fuel cell (sel bahan bakar) sebagai salah satu energi alternatif dapat menjadi pembangkit energi pada dunia otomotif 
dan mungkin akan bersaing bahkan akan menggeser tiga pilihan energi konvensional yang kini berkompetisi, yaitu; mesin pembakaran internal, mesin baterai isi ulang (rechargeable), dan mesin hibrida (Hasan, 2007).

Fuel cell memiliki potensi untuk efisiensi tinggi dan dapat mengubah sampai 75 persen energi pada bahan bakar alam. Fuel cell memiliki beberapa keuntungan pembakaran lebih konvensional berbasis teknologi saat ini yang digunakan dibanyak pembangkit listrikdankendaraan umum. Sistem energi terbarukan ini tidak memancarkan emisi pada saat operasi, termasuk green house gases dan polusi udara yang mengakibatkan berbagai masalah kesehatan. Selain itu fuel cell merupakan teknik yang unik dalam hal berbagai potensiaplikasinya, teknik tersebut dapat memberikan energi untuk sistem yang besar seperti pembangkit listrik dan laptop. Pada siklus dasar, jika hidrogen murni digunakan sebagai bahan bakar, fuel cell hanya memancarkan panas dan air sebagai produk sampingan. Oleh karena itu, pemanfaatan limbah cair menjadi energi listrik dengan metode fuel cell menjadi alternatif terbaik menanggulangi pencemaran dan toksisitas limbah cair laboratorium.

Berdasarkan latar belakang diatas, penelitian ini diharapkan dapat menjawab rumusan masalah sebagai berikut:

1. Bagaimana

proses pengolahan limbah cair laboratorium sebagai pembangkit listrik dengan metode fuell cell?

2. Pihak-pihak mana saja yang dapat membantu pengimplementasian pengolahan limbahcairlaboratorium sebagai media pembangkit listrik dengan metode fuell cell ?

3. Bagaimana langkah-langkah strategis proses pengolahan limbah cair laboratorium menjadi energi listrik?

\section{Tujuan Penelitian}

Dari latar belakang diatas, tujuan percobaannya adalah sebagi berikut:

1. Memanfaatkan limbah cairan di Laboratorium Terpadu FMIPA Universitas Islam Indonesia sebagai Pembangkit Listrik

2. Memberikan solusi penghematan listrik yang ekonomis dan terjangkau

3. Mengurangi pencemaran lingkungan oleh limbah cairan

4. Membantu pemerintah dalam mengatasi krisis listrik yang ada di Indonesia

Manfaat Penulisan

Manfaat penulisan gagsan tertulis ini diharapakan dapat memberikan wawasan ilmu pengetahuan dalam bidang teknologi pemanfaatan limbah cair dengan penggunaan limbah cair hasil praktikum sebagai media penghasil energi listrik yang dapat meminimalisirkan jumlah penggunaan listrik berbayar. 
Prohilila(Produksi....., Shalahuddin, Farida, Rohani, Shibghatun, Tiara

Adapun manfaat penulisan gagasan tertulis ini adalah sebagai berikut:

1. Bagi mahasiswa dapat menciptakan kreatifitas dan menumbuhkan semangat untuk berperan aktif dalam kegiatan pemanfaatan pengolahan limbah cair hasil praktikum menjadi engergi listrik

2. Bagi pengelola praktikum tidak kesulitan dalm pembuangan limbah hasil praktikum yang ada

3. Bagi pemerintah dapat dijadikan solusi dalam rangka Indonesia Hemat Listrik

\section{TINJAUAN PENELITIAN}

\section{Kondisi Kekiniaan Limbah di Laboratorium FMIPA}

Kriteria laboratorium yang baik untuk menentukan kandungan bahan pencemar dalam suatu sampel, berdasarkanketepatandannilaiakurasi sangat penting untuk diperhatikan. Faktor yang mempengaruhi dan menentukan validitas dari laboratorium antara lain :

1. Kelengkapan dan state of the art dari peralatannya

2. Kemampuan dan pengalaman dari operator atau analisisnya

3. Petunjuk analisis baku atau prosedur baku atau SOP yang digunakan

4. Kemampuan mengontrol mutu (Quality Control) dan pengendalian mutu (Quality Assurance) terhadap pekerjaan dan hasil analisis.

Laboratorium harus menerapkan
Good Laboratory Practice(GLP) dengan baik.Laboratorium yang ada di Indonesia sebagian telah memiliki sertifikasi Komite Akreditasi Nasional (KAN) namun sebagian juga belum. Fungsi dari Komite Akreditasi Nasional mengukur kemampuan laboratorium dan memantau pengecekan keakurasian dan kepresisian dari alat yang digunakan. KAN yang mewakili BSN(Badan Standarisasi Nasional) yang bertanggung jawab dalam bidang akreditasi khusus menentukan kompetensi laboratorium dengan pedoman SNI-19-17025-2000 yang diadopsi dari standar internasional ISO/IEC 17025-2000 yang merupakan standar sistem mutu oleh laboratorium penguji(Keputusan Ka.BAPEDAL No.113 Tahun 2000).

LaboratoriumFMIPAUIIYogyakarta dari observasi dari tahun 2008 yang memiliki kemampuan penanganan lingkungan terhadap limbah cair (zat kimia yang bersifat asam maupun basa berupa logam berat seperti Metanol, Eter, Sulfur, Merkuri yang paling sering dan sangat berbahaya, limbah padat seperti (sarung tangan, masker, jarum suntik, dan pecahan-pecahan gelas kaca, bahan alam, jas laboratorium, dan obat-obatan kadaluwarsa maupun limbah gas $\left(\mathrm{CO}_{2}, \mathrm{NO}_{2}, \mathrm{SO}_{2}\right)$ yang paling sering dan berbahaya. Laboratorium FMIPA mempunyai enam laboratorium yaitu Lab.Biologi Farmasi, Lab. farmasetika, Lab. Farmakoterapi, Lab. Kimia Farmasi, 
Lab.Mikrobiologi,

Lab.Tekhnologi

Farmasi. Maka dapat disimpulkan bahwa limbah yang dihasilkan sangat banyak dan merugikan lingkungan, dan sampai saat ini pihak laboran belum ada penanganan lebih jauh terhadap limbah laboratorium FMIPA UII. Terutama limbah cair laboratorium yang mengalir melalui aliran tanah dapat mempengaruhi intensitas dan kualitas air sumur, mencemarkan lingkungan dan dapat menyebabkan kematian makhluk hidup. sehingga jika hal ini dibiarkan akan menjadi ancaman yang serius. Oleh karena itu, dibutuhkan solusi yang dapat menjadi alternatif persoalan dari limbah cair laboratorium.

\section{Solusi yang Pernah Ditawarkan Sebelumnya}

Solusi yang pernah ditawarkan sebelumnya bagi pihak laboran di Laboratorium FMIPA UII sejauh ini dalampenangananlimbahlaboratorium terkait limbah cair kimia/anorganik hanya sebatas dengan pengumpulan limbah dalam satu bulan mencapai 25 liter dari masing-masing laboratorium kimia dan mikrobiologi,kemudian hanya dilakukan penetralan bagi limbah yang memiliki sifat toksik kemudian pembuangan. Hal ini belum menyelesaikan masalah, karena tidak bisa dipastikan jika limbah cair yang sudah dinetralkan kemudian dibuang ke tanah sudah bebas dari zat kimia yang berbahaya.

Mengenai kondisi ini, pengendalian masalah limbah di Laboratorium dengan cara dinetralkan saja tidak cukup memberikan jaminan kepada massyarakat sekitar. Karena limbah yang mengalir melalui aliran tanah dapat mempengaruhi intensitas dan kualitas air sumur, sehingga jika hal ini dibiarkan akan menjadi ancaman yang serius. Oleh karena itu, dibutuhkan solusi yang dapat menjadi alternatif persoalan dari limbah cair laboratorium.

Solusi yang ditawarkan disini yaitu dengan pemanfaatan metode fuel cel. Metode ini diharapkan dapat menjadi pilihan terbaik pemanfaatan limbah laboratorium yang semula tidak memiliki nilai guna ataupun ekonomi, dengan dimanfaatkan sebagai energi pembangkit listrik dapat mengurangi jumlah limbah dan tentunya zat toksik senyawa kimia yang terdapat pada limbah menjadi tidak berbahaya bagi manusia dan lingkungan. Sehingga diharapkan solusi ini dapat memberikan tawaran kepada pihak laboran dan memberikan jaminan kepada masyarakat sekitar lab karena lingkungan masyarakat tidak akan tercemar kembali.

\section{Kondisi Kedepan}

Konsumsi listrik Indonesia setiap tahunnya terus meningkat sejalan dengan peningkatan pertumbuhan ekonomi nasional. Prakiraan kebutuhan listrik jangka panjang di Indonesia sangat diperlukan agar dapat menggambarkan kondisi 
kelistrikan saat ini dan masa datang.

Diketahuinya perkiraan kebutuhan listrik jangka panjang antara tahun 2003 hingga tahun 2020 akan dapat ditentukan jenis dan perkiraan kapasitas pembangkit listrik yang dibutuhkan di Indonesia selama kurun waktu tersebut.

Dewasa ini kebutuhan listrik di Indonesia semakin meningkat. Tidak hanya untuk penggunaan rumah tangga, juga dalam penggunaan industri terus meningkat. Hal ini menyebabakan pemerintah selaku aparat negara harus memikirkan bagaimana memenuhi kebutuhan listik untuk seluruh Indonesia. Adanya gagasan ini, Laboratorium Terpadu

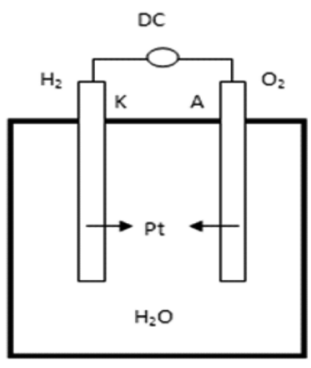

Kolam Penampung

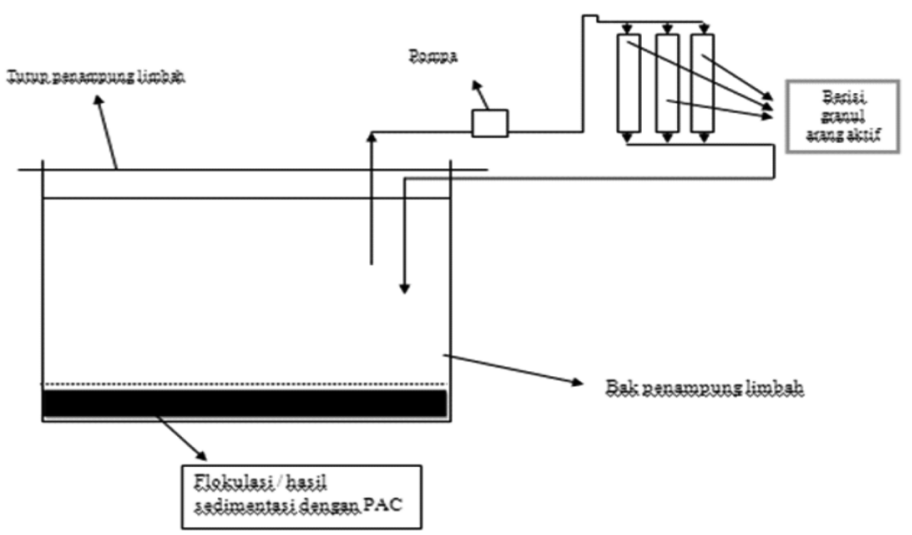

Desain karya Pengolahan limbah dengan metode fuell cell. Oleh: Shalahuddin dkk, Universitas Islam Indonesia.

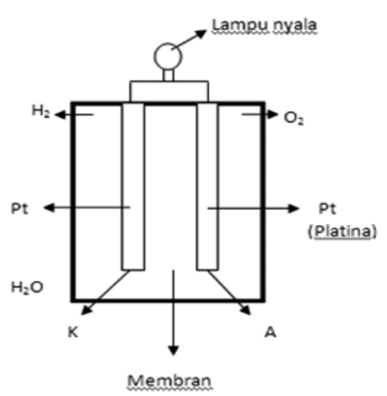

FMIPA Universitas Islam Indonesia dapat memasok pasokan listrik sendiri untuk kebutuhan laboratorium. Ini berarti tidak ada pembebanan biaya listrik lagi terhadap pihak Universitas. Alokasi biaya listrik dapat dimanfaatkan untuk pembiayaan kebutuhan Universitas yang lainnya. Jika sudah bisa menghasilkan energi listrik sendiri, Laboratorium akan lebih mandiri dan tidak ada gangguan pada saat praktikum karena listrik padam.

\section{RANCANGAN PENELITIAN}

Adapun rancangan pengolahan limbah menjadi energi listrik dengan metode Fuel Cell dalam percobaan ini adalah sebagai gambar berikut: 


\section{PEMBAHASAN}

Proses Kerja Pengolahan Limbah Cair Laboratorium sebagai Pembangkit Listrik dengan Metode fuell cell.

Adapun Proses kerja fuel cell ini melalui reaksi sebagai berikut:

Anoda

$$
: \mathrm{H}_{2} \rightarrow 2 \mathrm{H}^{+}+2 \mathrm{e}^{-}
$$

Katoda

$$
: 1 / 2 \mathrm{O}_{2}+2 \mathrm{e}-\mathrm{O}_{2} \text { - }
$$

Redoks Total : $\mathrm{H}_{2}+1 / 2 \mathrm{O}_{2} \rightarrow \mathrm{H}_{2} \mathrm{O}$

Fuel masuk anoda, kemudian oleh katalis dioksidasi menghasilkan elektron dan $\mathrm{H}^{+}$. $\mathrm{H}^{+}$langsung bergerak menuju katoda melalui eletrolit sedangkan elektron melakukan work pada load kemudian menuju katoda. Disisi lain, udara yang masuk katoda direduksi katalis menghasilkan ion $\mathrm{O}^{2-}$. $\mathrm{O}^{2-}$ bereaksi dengan $\mathrm{H}^{+}$membentuk $\mathrm{H}_{2} \mathrm{O}$ yang mengalir disel. Sel yang disuplai dengan hydrogen dan oksigen, maka akan menghasilkan listrik.

Melalui pemanfaatan ini, limbah cair praktikum tidak dibuang sembarangan sehingga tidak membuat pencemaran lingkungan yang notabene sebagai habitat manusia dimuka bumi ini yang apabila tercemar tentunya dapat menganggu kelangsungan makhluk hidup tersebut. Daerah Kabupaten Sleman terdapat empat Perguruan tinggi yang mana masing-masingnya mempunyai Laboratorium dan akan menghasilkan limbah. Diharapkan ke empat Perguruan Tinggi tersebut mampu mengolah limbah cair hasil praktikum dan memanfaatkannya sebagai sumber energi listrik. Jika satu Perguruan Tinggi dalam masa praktikumnya dapat menghasilkan 30-35 Liter/ bulan limbah cair maka dapat kita hitung berapa watt kita akan hemat listrik dari limbah yang semula tidak berguna.

Adanya gagasan ini, kedepannya diharapkan Laboratorium yang ada di setiap Universitas dapat mensuplai energi listrik dari hasil pemanfaatan limbah cair laboratorium yang dihasilkan setiap praktikum dengan menggunakan limbah cair. Apabila metode pengolahan limbah laboratorium menjadi energi listrik ini dapat diterapkan, dapat dipastikan bahwa pencemaran lingkungan karena limbah tidak akan terminimalisir. Begitu juga dengan kekhawatiran masyarakat tentang zat toksik dari limbah praktikum akan terjawab dengan aman. Sehingga akan tercipta laboratorium yang mandiri dengan pemanfaatan limbah hasil praktikum sendiri, yang nantinya akan menghemat pengeluaran biaya listrik. Hal ini tentunya dapat membantu Indonesia dalam memenuhi kebutuhan listrik setiap tahunnya.

Pihak- Pihak yang Dapat Membantu Pengimplementasian Pengolahan Limbah Cair Laboratorium sebagai Media Pembangkit Listrik dengan Metode Fuell cell.

Adapun pihak-pihak yang dapat membantu proses pengimplementasian gagasan ini, 
diantaranya mahasiswa FMIPA yang nantinya menjadi pelaku utama dalam proses pemanfaatan limbah laboratorium menjadi pembangkit listrik. Kemudian laboran yang mengurusi lab, untuk bekerjasama agar limbah lab bisa dimanfaatkan dalam penelitian ini.Kemudian fakultas, dan universitas untuk dapat memanfaatkan limbah lab cair di setiap fakultas untuk mendukung program pembangkit listrik tenaga limbah cair.

Gagasan ini dapat diterapkan oleh semua universitas yang mempunyai laboratorium kimia.Kerjasama dengan masyarakat sekitar untuk juga dapat mengalirkan manfaat dari energi listrik yang dihasilkan. Mengenai hal ini, juga dapat bekerjasama dengan PLN dan pemerintah pada khususnya untuk pengembangan tenaga listrik dalam skala yang lebih besar dalam upaya penghematan listrik di Indonesia.

\section{Langkah-langkah Strategis} Proses Pengolahan limbah cair laboratorium menjadi energi listrik

Proses pengolahan limbah cair laboratorium menjadi energi listrik meliputi beberapa tahapan atau proses yaitu:

1. Pengumpulan limbah cair

Proses pengumpulan limbah berlangsung setiap hari, ketika berlangsungnya praktikum mahassiswa di laboratorium FMIPA UII, kemudian setiap bulan sekali ada mengumpulan dari setiap lab untuk dikumpulkan dalam satu tempat yang akan siap untuk proses berikutnya.

2. Netralisasi

Limbah cair laboratorium mengandung banyak zat-zat kimia yang tidak diketahui dan berbahaya karena bersifat toksik/ racun.Mengingat tidak semua praktikan membuang limbah hasil praktikumnya pada tempat yang dibedakan antara yang asam dan basa. Oleh karena itu, diperlukan proses penetralan untuk menetralkan limbah cair laboratorium agar tidak toksik. Proses penetralan limbah cair ini dapat menggunakan arang aktif Arang aktif adalah suatu bentuk karbon yang mempunyai sifat absorptive terhadap larutan ataupun uap sehingga bahan tersebut dapat berfungsi sebagai penjernihan larutan, penghisap gas/racun dan penghilang warna. Arang aktif telah digunakan secara luas di dalam industri kimia, makanan, dan farmasi seperti untuk pembuatan minyak makan, obat sakit perut, penjernihan air minum, pembuatan gula pasir, masker dan lain-lain (Sudrajat, 1985).

3. Elektrolisis

Elektrolisis ini merupakan pemecahan limbah cair yang sudah dinetralkan menggunakan elektroda platina. Limbah cair yang sudah dinetralkan mengandung 
molekul air akan dipecah menjadi senyawa $\mathrm{H}_{2}$ dan $\mathrm{O}_{2}$ dimana dalam setiap pemecahan yang menghasilkan $\mathrm{H}_{2}$ akan dihasilkan pula energi listrik sebesar 1.23 Volt. Semakin banyak kolam elektrolisis yang dibuat akan semain banyak dan cepat juga pemecahan molekul air. Sehingga energi listrik yang dihasilkan juga semakin banyak.

4. Mengalirkan ke sumber listrik Energi listik yang dihasilkan dari elektrolisis kemudian di gabungkan atau diakumulasikan sehingga energinya semakin besar. Jumlah energi total yang dihasilkan sama dengan jumlah yang cukup. Selanjutnya di alirkan ke sumber tegangan listrik. Limbah cair laboratorium dari praktikum dapat menghasilkan 30-35 Liter/ bulan. Dari data tersebut dapat dihasilkan $3.33 \mathrm{~kg} \mathrm{H}_{2}$ dan dikonversikan menjadi 112870 watt per jamnya.

Hasil konversi ini didapat melalui reaksi berikut

Redoks Total : $\mathrm{H}_{2}+1 / 2 \mathrm{O}_{2} \rightarrow \mathrm{H}_{2} \mathrm{O}$

Satu molekul $\mathrm{H}_{2} \mathrm{O}$ dapat menghasilkan 1666.67 mol $\mathrm{H}_{2} \mathrm{O}$ yang setara dengan $3.33 \mathrm{~kg} \mathrm{H}_{2}$. satu $\mathrm{kg} \mathrm{H}_{2}$ dapat menghasilkan 33,9 kWh energi listrik atau sama dengan 33.900 watt per jam.

\section{PENUTUP}

\section{Gagasan yang Diajukan}

Gagasan yang kami ajukan yaitu memproduksi hidrogen dari limbah laboratorium dengan metode fuel cell sebagai upaya untuk memanfaatkan limbah yang biasanya hanya dibuang pada tanah resapan. Pemanfaatan limbah ini dirasa sangat penting mengingat limbah yang dihasilkan oleh laboratorium bersifat toksik dan dapat merusak lingkungan sekitar pembuangan limbah.

Realisasi dari gagasan ini adalah dilakukannya kajian untuk mengetahui lebih lanjut produksi hydrogen dengan metode fuel cell dengan bahan bakar limbah laboratorium yang telah dinetralisasi. Hal tersebut merupakan salah satu alternative untuk menghasilkan energi listrik dan sebagai upaya untuk mengurangi jumlah limbah toksik yang dibuang ke lingkungan.Selain itu juga sebagai upaya penghematan penggunaan energi listrik.

\section{Teknik Pengimplementasian}

Implementasi yang dilakukan adalah dengan melakukan studi lebih lanjut mengenai cara proses pemanfaatan limbah menjadi energi listrik menggunakan metode fuel cell. Sehingga dapat menguatkan gagasan yang ada untuk benar-benar dapat terealisasi dengan lancar, untuk memberikan solusi yang tepat, selain itu juga dapat dimanfaatkan untuk memanfaatkan limbah cair laboratorium sebagai energi listrik terbarukan yang dapat mencegah efek toksik yang dihasilkan dari zatzat kimia yang terkandung dalam 
limbah cair laboratorium. Setelah data yang dikumpulkan lengkap, langkah selanjutnya yaitu menerapkan data tersebut untuk dapat diwujudkan dalam bentuk yang nyata. Sehingga sumbangan pemikiran dari ide kreatif ini dapat bermanfaat. Energi yang dihasilkan dari metode fuel cell ini, nantinya dapat digunakan untuk energi alat komunikasi seperti laptop, handphone, televisi, alat penerangan laboratorium sampai eskalator atau lift yang ada digedung laboratorium.

\section{Prediksi Hasil}

Prediksi hasil yang akan dicapai dari gagasan produksi hydrogen dari limbah laboratorium dengan metode fuel cell yaitu memberikan kemandirian kepada laboratorium untuk menghasilkan energi listrik dengan memanfaatkan limbah yang diproduksi. Selain itu juga sebagai inovasi dalam mengembangkan teknologi fuel cell yang dapat digunakan sebagai pembangkit tenaga listrik nasional yang efisien. Dan juga sebagai program penyelamatan lingkungan akibat kerusakan yang disebabkan oleh pencemaran limbah cair kimia serta menjamin pemerintah dalam memberikan solusi untuk menghasilkan energi yang terbarukan.

\section{REKOMENDASI}

1. Penelitian selanjutnya diharapkan untuk meningkatkan daya yang dapat dihasilkan dari limbah cair, sehingga dapat dimanfaatkan dalam daya yang besar.

2. Diharapkan penelitian lebih lanjut untuk menggunakan limbah lain, sehingga metode fuell cell dapat meminimalkan efek negative dari pencemaran limbah.

3. Perlu dilakukan inovasi dari desain alat agar dapat dibuat lebih sederhana dan efisien.

\section{DAFTAR PUSTAKA}

Anonim.2011. Panduan Akademik 2011/ 2012 FMIPA. Yogyakarta: UII Press.

Anonim. 2000. Keputusan Kepala BAPEDAL No. 113 Tahun 2000 tentang Pedoman Umum dan Pedoman Teknis Laboratorium Lingkungan.

Anwar Hadi. 2007. Prinsip Pengelolaan Pengambilan Sampel Lingkungan.

Hasan, A. 2007.Aplikasi Sistem Fuel Cell Sebagai Energi Ramah LingkungandiSektorTransportasi dan Pembangkit, Jurnal Teknik Lingkungan. Vol. 8 No.3.

Kardono. 2008. Persyaratan Laboratorium Lingkungan dan Kondisinya di Indonesia, Jakarta: J.Tek.Ling.Vol.9 No.2. HIm113115.

Sudarjat, dkk. 2011. Pengaruh Grain Size Arang Aktif dari Bahan Limbah Industri Sagu Aren 
KHAZANAH, Vol. 6 No.2 Januari 2014

terhadap Penyerapan Polutan Limbah Batik , Jurnal IImiah Semesta Teknika. Vol. 14, No. 1: 86-93.

Supraptini.2007. Pengaruh Limbah Industri Terhadap Lingkungan Di Indonesia.Media Litbang Kesehatan Volume XII Nomor 2 tahun 2002.

Tanjung S, Djalal. 2002. Dasar-Dasar Ekologi Lingkungan Hidup
Pusat Studi Lingkungan Hidup. Yogyakarta: Universitas Gajah Mada Press.

Thomas, Timmreck C. 2005. Epidemiologi: suatu pengantar Edisi 2. Jakarta: EGC.

Penelitian ini dibimbing Oleh: Arba Pramundita Ramadhani M.Sc Apt dan Riyanto Phd * Dosen FMIPA UII. 